\title{
AMBON DI BAWAH ORDE BARU: TRANSFORMASI KAPITALISME PADA MASYARAKAT PINGGIRAN
}

\author{
Hatib Kadir \\ Staf Pengajar Antropologi, FIB-Universitas Brawijaya \\ *) Email: hatibkadir@gmail.com
}

\begin{abstract}
:
Using the approach of Karl Polanyi (2014), this paper studies three great transformation take place in Ambon Island during the 1970s to 1990s. Those transformation are on land, money and transportation. Money transforms local people to acquaint with the price system. On the other hand, the needs of consumption increase when money is introduced. Using money, local Moluccans can send their children to the higher school as well as allocate to buy more machinery works. The machinization also accelerates rural people to work faster and more efficient. The questions from this paper is who are the people who bring all of these social and economic transformations? The author found that the coming of voluntary migrants from Sulawesi, Java, and Padangese any other Island in Indonesia play significant role to change the Moluccan system economic and social systems. These migrants dominate exchanges from the production level in the orchards to the rural and urban marketplaces. They play both as traders and middlemen. The Butonese, migrants from Sulawesi, are the most significant suppliers and middlemen that bring rural commodities to sell to the Chinese Moluccan in the city. Chinese Moluccan mostly are shop owners who do not have a direct in touch with the local Moluccan landowners in the rural areas. They also play a role as moneylender for Butonese to buy cloves and nutmeg from the rural areas. Therefore, it is Butonese that have direct contact with the rural Moluccans. Despite the authoritarian regime of the New Order, in the economic field, the State tend to let people to constitute their own business, before finally in the mid of 1990s, The Clove Support and Trading Board (BPPC) under the authority of Tommy Suharto, the son of Indonesian President, took over the business by monopolize the clove trade system.
\end{abstract}

Keywords: Economic Transformation, ethnic economy, exchanges, middlemen, monetization.

\section{PENDAHULUAN}

Tulisan ini mengksplorasi tiga transformasi besar yang terjadi di Ambon selama masa Orde Baru. Terdapat perubahan-perubahan penting di Ambon selama tahun tahun 1970an hingga 1990an. Pertama adalah terjadinya monetisasi karena harga cengkeh dan pala yang naik di pasaran nasional dan menyebabkan meningkatnya jumlah kredit dan hutang antar etnis yang meningkat. Kedua, privatisasi tanah dan komodifikasi pohon. Harga cengkeh yang meningkat pada tahun 1970 hingga akhir 1980an yang menyebabkan sejumlah ketegangan dan meningkatnya kasus-kasus di pengadilan berkenaan dengan properti tanah dan pohon. Kebanyakan konflik disebabkan oleh kepemilikan tanah dan bagi hasil antara pemilik tanah masyarakat pribumi dan komunitas pendatang. Ketiga, saya menggunakan konsep "motorisasi" yang terjadi semenjak meningkatnya transportasi di tahun 1980an. Tiga transformasi ini meningkatkan perubahan pola ekonomi interaksi dan struktur social. 
Sejak awal tahun 1970 banyak migran/ pendatang yang tertarik untuk tinggal di beberapa distrik kecil seperti Tulehu, Passo dan Poka. Otto Hospes misalnya melaporkan bahwa sebuah distrik bernama Tulehu, banyak penduduk migran dari Buton yang terlibat dalam perdagangan cengkeh. ${ }^{1}$ Di samping itu telah banyak orang Cina Maluku, Sumatera, dan Jawa yang mendominasi bekerja sebagai pemilik toko dan restoran. Pada bulan November 1989, Hospes mencatat bahwa terdapat 118 toko, dimanal) sekitar 40 persennya adalah toko kecil yang dimilik oleh masyarakat asli Ambon, sedangkan, 46 persen adalah toko menengah yang dimiliki oleh masyarakat keturunan Buton (saya menyebutnya Buton Maluku) dan Sumatra dan sisa 10 persen adalah toko menengah dan besar yang dimiliki oleh orang Cina. ${ }^{2}$ Namun demikian, Hospes tidak menggambarkan secara detail jumlah populasi migran yang meningkat seiring dengan meningginya sirkulasi uang. Ia hanya menunjukkan bahwa sejumlah pedagang ButonMaluku meningkat di setiap kampung yang dekat hasil bumi seperti cengkeh, pala dan sagu. Orang Buton-Maluku juga tinggal di sekitar jalan besar dan sungai. Mereka sangat aktif di ranah pertanian dan perdagangan baik di perdesaan

\footnotetext{
1 Otto Hospes. 1996. People That Count: Changing Savings and Credit Practices in Ambon, Indonesia. Wageningen: publisher not identified. Thesis Wageningen Agricultural University. h.181.

${ }^{2}$ Ibid. h.232.
}

maupun perkotaan, perikanan, proses pembuatan sago hingga mereka juga menguasai kepemilikan moda transportasi publik. Jeroen Adam dalam disertasinya mencatat bahwa orang-orang ButonMaluku memang sengaja ditempatkan oleh masyarakat asli di kawasan-kawasan sungai yang sebenarnya merupakan perbatasan antara warga kampung Kristen dan Islam, misalnya seperti antara Said dan Kaitetu atau Liang dan Waai. ${ }^{3}$

\section{PEMBAHASAN}

\section{Periode Monetisasi dan Privatisasi Tanah yang Dramatis}

Monetisasi adalah pertumbuhan sirkulasi dan percepatan uang disekitar kehidupan sosial. Monetisasi terjadi karena munculnya komodifikasi tanaman dan mempunyai implikasi terhadap kehidupan sosial. Semenjak adanya monetisasi di Ambon, masyarakat tidak lagi berpikir hidup secara subsisten. Masyarakat tidak lagi memotong pohon sagu dan memancing ikan untuk menjamin suplai pangan, dan masyarakat tidak lagi membangun rumah dengan mengandalkan sistem kerja sama diantara para tetangga dan mengambil material rumah dari hutan. Monetisasi justru menstimulasi orang agar bagaimana caranya mendapatkan uang untuk membeli minyak, beras, ikan, jajanan, rokok dan sebagainya dengan uang kas. Dibanding

${ }^{3}$ Jeroen Adam. 2010. Communal violence, forced migration \& social change on the island of Ambon, Indonesia. Ghent: Ghent university 
mengambil semua kebutuhan hidup dari alam, seperti ikan dan sagu, masyarakat mulai dikenalkan dengan sistem "search money" (mancari uang) terlebih dahulu dalam mendapatkan berbagai hal yang dibutuhkan. Pada akhirnya, monetisasi menyebabkan orang terjebak ke dalam hutang karena ketika mereka tidak mempunyai uang tabungan atau ketika masa panen mengecewakan, semua kebutuhan hidup yang memerlukan uang, harus dipenuhi terlebih dahulu dengan cara berhutang. Sebagai hasilnya, masyarakat mulai mengenal peminjaman dari peminjam uang (moneylender) atau middlemen

Pada akhir tahun 1989, harga cengkeh terendah adalah dikisaran sekitar US\$2 per kilogram. Naiknya harga komoditas cengkeh otomatis meningkatkan kehidupan ekonomi masyarakat Maluku di pedesaaan dan di perkotaan, namun hal tersebut membawa beberapa konsekuensi ekonomi sosial. Masyarakat mulai mengkonsumsi beras secara lebih dan membangun rumah permanen tidak lagi dengan menggunakan material dari pohon sagu. Mengingat beras tidak dapat diproduksi di Pulau Ambon, masyarakat memerlukan uang untuk mengkonsumsinya. Impor barang berupa beras kemudian naik secara cepat. Disamping itu, sebagai akibat dari pergeseran konsumsi, terjadi relasi yang kuat antara sirkulasi uang dan sirkulasi hutang yang meningkat secara dramatis. Hal sebanding dengan transformasi ini adalah, orang Buton secara cepat merespon terhadap meningkatnya permintaan uang dengan cara mensuplai kredit yang ditukarkan dengan cengkeh ketika panen. Oleh karena itu, naiknya harga cengkeh mengintensifkan relasi antara orang Ambon dan orang Buton yang didasarkan pada relasi kredit dan hutang. Di samping itu, pedagang Tionghoa pemilik toko juga menawarkan kredit barang dan mereka mendapatkan sistem pembayaran hutang dalam bentuk cengkeh, dimana bunga pembayaran terhitung dalam harga produk yang dibayar.

Hospes menemukan bahwa meningkatnya tanaman komersial menyebabkan munculnya sistem tabungan dan beragam pengaturan kredit pada saat yang sama. Orang Buton memberikan kredit kepada para petani Ambon. Di beberapa distrik tertentu, orang Buton juga memainkan peranan penting sebagai pedagang dan pensuplai kredit. Meskipun para pedagang Buton atau Tionghoa pemilik toko memberikan sistem kredit dengan bunga tinggi, namun syarat hutang tidak serumit dari penawaran kredit dari bank. Pemilik toko Tionghoa mensuplai pinjaman dalam waktu satu hari, sedangkan prosedur pinjaman bank, semacam BRI (Bank Rakyat Indonesia) lebih rumit dan membutuhkan waktu sekitar satu minggu. Kemudahan untuk mengakses pinjaman, dalam hal ini menciptakan instrumen relasi antar etnis. 
Meningkatnya harga cengkeh menguntungkan orang Buton sebagai "makelar" atau perantara (middlemen). Mereka mampu membeli tanah, meskipun di beberapa kasus berakhir dengan konflik dengan orang Ambon asli yang mengklaim tanah tersebut. Di samping itu, beberapa pedagang Buton juga mampu menyewa kebun atau membelit hak panen pohon cengkeh dan pala. Hospes mencatat sebagai misal: La Batini and Wa Hanira datang ke Tulehu pada tahun 1979 dan sekarang mereka menyewa 22 gardens (kebun). Sepanjang periode antara April 1986 hingga Januari 1990, La Batini membeli hak panen 339 pohon pala dari 16 orang yang berbeda dengan total harga Rp. 1, 620, 000. Pada periode yang sama, ia juga membayar Rp, 1,680,000 untuk hak panen stujuh kebun cengkeh dalam beberapa musim. ${ }^{4}$ Perjanjian hutang atau negosiasi sewa-menyewa dilakukan untuk periode dua tahun. Semakin orang Buton menyewa sejumlah pohon, semakin lama periode kontraknya. Semakin banyak pohon cengkeh yang disewa, semakin murah harga sewa. Oleh karena itu, Orang Buton, para pedagang Buton yang mempunyai uang lebih, akan menyewa pohon dalam jangka waktu yang lama, misalnya adalah harga sewa untuk 13 pohon untuk satu tahun adalah Rp, 50,000, sedangkan untuk dua tahun kontrak adalah Rp,

\footnotetext{
${ }^{4}$ Ibid. h.81.
}

80, 000 dan Rp, 120,00 untuk tiga tahun kontrak dengan 15 pohon. Jika diperhatikan penemuan Hospes ini, kita dapat melihat bahwa pola kontrak menghubungkan antara orang Ambon pemilik lahan dengan pedagang Buton dalam kerangka sewa yang telah disepakati. Semakin orang Buton mempunyai uang, semakin intensif relasinya dengan orang Ambon pemilik pohon cengkeh. Tanah tidak hanya lebih bernilai karena tekanan penduduk, namun juga karena harga tanaman pangan yang meningkat secara tajam. Oleh karena itu, ketika harga cengkeh, kopra dan lada naik, semakin masyarakat memerlukan tanah untuk menanam tanaman komersial tersebut.

Orang Buton mempunyai kemampuan untuk menfinansialkan hasil bumi, yang tidak hanya terdiri dari cengkeh, namun juga kopra, lada, pala, durian dan kelapa. Banyak dari mereka yang mengembangkan jaringan dengan para pemilik toko dan pedagang besar (wholesaler) Tionghoa sebagai partner. Dibanding orang Tionghoa, orang-orang Buton adalah pedagang yang datang langsung ke petani cengkeh atau pemilik pohon untuk melakukan bisnis. Oleh karena itu, di ranah akar rumput, orang Buton mempunyai relasi yang lebih intensif dengan pribumi Ambon dibanding dengan pedagang Tionghoa.

Orang Buton mempunya relasi yang intensif khususnya ketika proses pra-panen dan selama masa pengaturan panen sagu dan cengkeh. 
Mereka juga berpartisipasi dalam pemotongan sagu dan pendistribusian penjualan. Orang Buton mempunyai beragam mekanisme dalam membeli atau pula menyewa pohon-pohon dari orang Ambon. Sedangkan pemberi hutang (money lender) atau penjaga toko memberikan kredit dalam bentuk uang atau barang konsumsi, yang akan dibayar dengan cengkeh. Untuk menghitung hutang, transaksi menggunakan harga fiktif dengan standar yang rendah. Sebagai misal, ketika penyuplai cengkeh meminjam 100 ribu rupiah dalam bentuk konsumsi barang atau dalam uang kas, maka ketika masa panen ia harus membayar kembali pinjamannya dengan 50 kilogram cengkeh.

Contoh bagan sederhana diatas menunjukkan bahwa masyarakat terhubungkan melalui relasi rantai suplai cengkeh. Selama masa panen koneksi rantai suplai ini lebih intensif. Hospes memberikan contoh Pak Su, seorang perantara berasal dari Jawa. Ia menyuplai barang konsumsi hingga ke wilayah kepulauan di Maluku, dan ia kembali ia ke kawasan tersebut ketika panen cengkeh tiba. Pada tahun 19891990, Pak Su menyediakan barang-barang ke 74 pemilik toko dari berbagai etnis di dua belas perdesaan di kawasan pantai. Ia menyuplai 17 orang Buton pemilik toko, 15 pedagang Bugis, 9 pedagang Tionghoa, 7 pedagang Jawa, 7 pedagang asli Ambon, 5 pedagang Maluku Tenggara, 4 pedagang Sulawesi dari Toraja, 3 pedagang Sumatera, 1 pedagang kota Ambon, 1 KUD, 1 pedagang Arab dan satu tidak diketaui etnisnya. ${ }^{5}$ Perantara memainkan peranan penting sebagai penyuplai barang-barang ke perdesaan dan juga sebagai peminjam uang. Sebagai gantinya, Pak Su mendapatkan harga fiktif sebelum panen yang dengan standar yang rendah.

Setelah mengumpulkan cengkeh, perantara menyuplai ke agen-agen besar di kota Ambon. Sebagai gantinya, para agen ini memberi beras, gula dan berbagai barang lainnya kepada perantara untuk menyuplai kembali para pemilik toko-toko kecil di perdesaan. Rantai suplai ini sesungguhnya digerakkan oleh hutang karena di tingkatan paling atas, agen rokok menyediakan hutang kepada toko-toko grosir untuk memberikan hutang kembali kepada perantara yang akan memberikan hutang kepada pedagangpedagang kecil. Dari tahun 1973 hingga 1980, agen-agen rokok seperti dari Gudang Garam menyuplai 10 juta kepada toko grosir. Dan toko grosir membayar kembali dengan dua ton cengkeh dengan harga Rp,5000 per kilogramnya. ${ }^{6}$ Sementara Pak Su sendiri, pada tahun 1977, mendapatkan pinjaman dari bank sebanyak 3 juta rupiah. Pada awal tahun 1990an hutangnya semakin besar karena ia meminjam 60 juta dari totak kredit investasi kecil (15 juta rupiah) dan Kredit Modal Kerja Permanen (45 juta).

\footnotetext{
${ }^{5}$ Ibid. h.234-235.

${ }^{6}$ Ibid. h.237.
} 
Bersamaan dengan waktu, marjin bentuk moda produksi lainnya, mereka keuntungan Pak Su menurun karena mengalami kesulitan dalam mengakses pinjaman meningkatnya jumlah perantara. Diantaranya yang diberikan oleh bank-bank lokal. Oleh karena adalah masuknya para pedagang Cina yang menguasai transportasi dalam jumlah besar untuk mensuplai barang-barang ke perdesaan. Pedagang Tionghoa mempunyai perahu mesin (johnson) dan bis mini yang tidak hanya mampu membawa penumpang, namun juga mendominasi jaringan dagang dan mendistribusi barang-barang impor.

Periode naiknya harga cengkeh secara tajam mempunyai intesifikasi relasi sosial antar etnis. Hutang dan kredit tidak untuk mengontrol relasi atau memonopoli rantai suplai, tapi lebih merupakan pemberian (gifts) yang bertujuan untuk meneruskan relasi sosial berdasarkan kepercayaan antara pedagang migran dan para petani Ambon. Hutang menyebabkan relasi sosial secara gradual karena hutang antara petani cengkeh dan peminjam uang bersifat mengikat. Jika petani meminjam uang ke bank, ia masih mempunyai kebebasan untuk menjual produksinya, namun jika ia mendapatkan pinjaman dari perantara, maka ia harus menjual produksinya hanya pada perantara tersebut.

Di sisi lain, meningkatnya sirkulasi uang pada akhir tahun 1970an menstimulasi bank, seperti Bank Rakyat Indonesia (BRI) untuk memunculkan beragam program kredit. Namun demikian, masyarakat yang tidak mempunyai pekerjaan tetap dan modal, seperti tanah dan

itu, para pedagang dan petani cenderung membangun jaringan hutang dengan para pedagang migran atau pemilik toko Tionghoa yang juga berperan sebagai peminjam uang (moneylender). Pinjaman tidak hanya bersifat untuk pemenuhan kebutuhan diri, tapi juga bertujuan untuk menjaga relasi antara petani dengan para pedagang migran dan pedagang Tionghoa. Tanpa pinjaman hutang, masyarakat hampir tidak dapat meningkatkan mata pencaharian dan perkembangan ekonomi mereka. Karena itu, mendapatkan pinjaman sebenarnya menciptakan semacam kecemasan karena uang tidak dapat disimpan agar tak teregresi ke inflasi. Dengan demikian, uang pinjaman harus diputar ke dalam aktivitas ekonomi untuk melahirkan bentuk modal yang lainnya. Pinjaman tidak hanya dalam bentuk transfer uang, tapi juga barang. Penerima barang, biasanya sudah saling mengenal. Karena itu pinjaman lebih didasarkan pada permasalahan kepercayaan. Jenis pinjaman lainnya dapat dalam bentuk properti tanah. Menyewa pohon berarti meminjam tanah secara temporer hingga cengkeh masak dan siap dipanen. Kepercayaan dalam meminjamkan tanah dapat dianggap sebagai sebuah kepercayaan. Dengan kata lain, penduduk asli Ambon yang menyewakan tanahnya mempunyai kepercayaan 
terhadap migran karena mereka dapat dipercaya membayar dengan tepat waktu. Dengan demikian, rantai hutang sebenarnya menunjukkan bahwa masyarakat tertanam dalam beragam relasi sosial antara pemberi dan penerima, pemilik dan penyewa. Dengan demikian, kepemilikan temporer terhadap pohon dan juga hutang dapat dilihat sebagai kinerja pedagang untuk menjaga relasinya dengan pemilik tanah dan menjaga kepercayaan untuk kelanjutan variasi sistem kredit di masa depannya.

Monetisasi dan relasinya kepada relasi sosial menunjukkan bahwa uang mempunyai dua ambiguitas dalam mengintegrasikan dan mendisintegrasikan masyarakat. Uang mendisintegrasikan masyarakat karena pertumbuhan kecepatannya dapat menggantikan semua relasi sosial melalui uang. Sebagai misal, dibanding melibatkan para tetangga atau saudara untuk membangun rumah bersama (masohi), masyarakat yang mempunyai uang dan dapat membeli material rumah dan mempekerjakan orang lain untuk bekerja membangun rumahnya. Semenjak tradisi masohi mulai ditinggalkan, toko mempunyai peranan penting. Orang tidak lagi menggunakan batang dan daun sagu sebagai rumah dan tidak lagi menggunakan tenaga tetangga untuk membangun rumah. Karena mempunyai uang, masyarakat mulai mengandalkan material perumahan dari toko. Keperluan material perumahan menyebabkan toko mempunyai peranan sebagai "bank". Daripada meminjam uang dari bank untuk membangun rumah, masyarakat Maluku cenderung meminjam dalam bentuk material rumah secara langsung dari orang Tionghoa pemilik toko grosis. Sebagai gantinya, masyarakat akan menggantinnya dengan cengkeh ketika membayar.

Di samping itu, monetisasi juga berimplikasi pada ketergantungan terhadap saudara dan tetangga. Ketika musim panen cengkeh belum datang atau ketika harga panen cengkeh menurun di pasaran nasional, jumlah hutang meningkat diantara para petani. Namun demikian, tidak benar pula jika kita menyimpulkan bahwa monetisasi telah mengurangi ikatan sosial keluarga dan tetangga secara keseluruhan. Pertumbuhan uang juga menyebabkan masyarakat membelanjakan uangnya untuk mengirim anak ke pendidikan yang lebih tinggi, pergi haji, dan membantu saudara di rumah sakit. Mengirim anak ke sekolah menjadi salah satu investasi di masa depan. Dengan mempunyai pendidikan yang lebih tinggi, anak akan mampu mendapatkan pekerjaan dengan gaji layak dan dapat menjamin keamanan sosial orang tua mereka di masa depan. $^{7}$

${ }^{7}$ Benda-Beckmann, Franz von and Keebet von Benda-Beckmann. 2007. Social Security 
2) Pertumbuhan Motorisasi dan Mekanisasi Mode Produksi

Motorisasi transportasi darat dan laut dapat meningkatkan distribusi tanaman komersial dan produksi laut. Orang yang berasal dari kawasan terpencil dapat meningkatkan barangbarang impor dari kota Ambon. Di samping itu, pertumbuhan sirkulasi uang juga beriringan dengan meningkatnya motorisasi, karena semua transportasi mesin dapat menangkut jumlah komoditas dalam jumlah yang lebih besar.

Mekanisasi juga terjadi dalam mode produksi sagu. Hanya sedikit orang yang mempunyai mesin untuk memarut sagu. Lama proses pengambilan inti sagu dengan tidak menggunakan mesin membutuhkan waktu dua kali waktu dibanding menggunakan mesin. Semenjak monetisasi, mesin menjadi penting untuk memproduksi sagu. Harga dari sagu tergantung dari ketebalan pohon dan juga jarak dari rumah. Pada awal tahun 1990an, satu pohon sagu besar dapat menghasilkan 40 keranjang sagu dengan harga sewa pohon $\mathrm{Rp}, 25$, ribu. Tidak seperti pertanian padi, pemanenan sagu tidak melibatkan banyak tenaga kerja. Pemanenan sagu dan pemotongan hanya memerlukan dua atau tiga hari dengan tiga pekerja, yang biasanya melibatkan orang-orang Buton dan saudaranya.

Between Past and Future. Ambonese Networks of Care and Support. LIT Verlag

Munster.
Sagu menjadi investasi selain cengkeh. Selama sebelum musim panen, banyak pedagang Buton yang menginvestasikan uang mereka di pohon sagu. Meskipun demikian, selama musim cengkeh, orang Buton tidak memotong pohon sagu, namun mereka mengalokasikan uangnya untuk membeli buah cengkeh (beli buah) or atau cengkeh yang baru panen (beli cupa).

Pedagang Buton juga mendominasi kepemilikan teknologi produksi tingkat rendah, seperti sampan dan bagan (perahu rakit). Perangkat ini sangat penting untuk menangkap ikan-ikan kecil untuk keperluan subsisten dan uang kas dalam waktu cepat. Hospes mencatat bahwa pada akhir tahun 1980an, orang Buton memiliki hampir semua bagan. Harga bagan untuk ukuran menengah lebih murah dibanding perahu motor, yakni sekitar 2 juta rupiah. Namun demikian, karena perlu waktu lama untuk menangkap ikan di sekitar pantai, menjadi nelayan bukanlah pekerjaan utama. Semenjak perubahan transportasi laut sangat pesat, orang Buton juga mulai mempunyai perahu motor yang lebih besar dan lebih cepat. Pada tahun 1987, sebuah harga perahu motor di pelelangan berkisar antara Rp, 15,5 million, namun pemasukan dari hasil menangkap ikan dalam satu hari jauh lebih banyak dibanding dengan bagan. Disamping menjadi seorang pedagang, salah satu alasan orang Buton untuk bekerja sebagai nelayan adalah karena mereka tidak mempunyai hak 
kepemilikan tanah. Karena itu, laut adalah ruang terbuka dimana setiap orang dapat mengakses hasilnya. Selain itu, menurunya harga cengkeh di akhir tahun 1980an juga membuat orang Buton mengalihkan bagian dari investasinya ke perikanan dan transportasi darat.

Pada tahun 1990an, orang Buton juga mulai mempunyai transportasi darat (minibus). Mereka membeli satu atau dua minibus dan mempekerjakan setidaknya dua orang asli Maluku. Bartels mencatat bahwa pada tahun 1970an, mekanisme rekrutmen transportasi darat masih melibatkan relasi pela. Sebagai misal, jika sopir adalah berasal dari Passo, kondektur berasal dari Batumerah. ${ }^{8}$ Namun demikian, ketika orang Buton dan Tionghoa mendominasi mode transportasi modern berukuran besar, mereka tidak mengaplikasikan sistem pela ini, sebagai gantinya mereka merekrut pekerja berdasarkan klan mereka sendiri. Atau orang-orang Buton yang mempekerjakan masyarakat Maluku asli yang tidak mempunyai ikatan keluarga dengan si pemilik mode produksi. Roy Ellen mencatat bahwa mekanisasi transportasi yang memutus relasi keluarga dan kerabat juga terjadi dalam transportasi darat. ${ }^{9}$

${ }^{8}$ Dieter Bartels. 1977, "Guarding the invisible mountain: inter village alliances, religious syncretism and ethnic identity among Ambonese Christians and Moslems in the

Moluccas” PhD Dissertation, Cornell University, 1977

${ }^{9}$ Ellen, Roy. 2002. "Pengetahuan tentang hutan, transformasi hutan : ketidakpastian politik, sejarah ekologi,

\section{KESIMPULAN}

James Scott mencatat bahwa meningkatnya kekerasan dengan skala kecil dan kecemburuan sosial mekanisasi produksi yang bertujuan untuk meningkatkan hasil produksi. ${ }^{10}$ Meski berbeda dengan studi James Scott di Malaysia yang beriringan dengan munculnya revolusi hijau, meningkatnya mekanisasi produksi di Maluku juga menyerupai dengan yang terjadi di Malaysia. Meski pohon-pohon cengkeh tidak mampu ditingkatkan produksinya melalui intensfikasi teknologi seperti padi, meningkatnya konsentrasi kepemilikan alat produksi pada beberapa pihak, khususnya migran Buton dan Bugis mendatangkan banyak pertengkaran dan kecemburuan ekonomi yang hebat. Benda Beckmann misalnya mencatat bahwa meningkatnya litigasi atau kasus kasus perdata dan pidana di pengadilan negeri, seiring dengan meningkatnya harga dan produksi cengkeh dipasaran. ${ }^{11}$ Konflik antara pendatang dan masyarat asli meningkat karena beberapa alasan, seperti konflik kepemilikan tanah dan

dan renegosiasi terhadap alam di Seram Tengah" dalam Proses Transformasi Daerah Pedalaman di Indonesia edited by Tania Li. Yayasan Obor Indonesia.

10 James C. Scott. 2008. Weapons of the Weak: Everyday Forms of Peasant Resistance. Yale University Press.

${ }^{11}$ Benda-Beckmann, Franz von and Keebet von Benda-Beckmann. 2007. Social Security Between Past and Future. Ambonese Networks of Care and Support. LIT Verlag Munster. 
konflik orang-orang migran yang dianggap melanggar perjanjian untuk tidak boleh menanam tanaman permanen seperti cengkeh dan pala. Dari tiga transformasi yang terjadi privatisasi tanah, monetisasi dan mekanisasi alat produksi diatas, yang menjadi pertanyaan adalah apakah tiga transformasi kapitalisme ini merupakan salah satu penyebab konflik yang terjadi di Maluku pada transisi demokrasi 1998-1999? Tentu saja banyak alasan dan studi yang menjawab alasan konflik. Namun, tulisan ini belum sampai menganalisis pada tahap tersebut, melainkan tulisan selanjutnya akan melihat sejauh mana kekuasaan Negara Orde Baru yang dikatakan demikian kuat ada dimana-mana ternyata mempunyai batasnya khususnya dalam mengontrol roda kapitalisme masyarakat pedagang di Maluku. Simak kisah selanjutnya di bagian dua tentang "anarkisme orang Maluku dalam menghindari kontrol pasar yang dilakukan Negara Orde Baru.

Roy Ellen mencatat bahwa dua hal paling penting yang hilang dari transformasi kapitalisme modern di Ambon adalah hilangnya tradisi masohi dan sosolot. Masohi adalah sistem gotong royong antar tetangga dan saudara khususnya dalam membangun rumah atau berbagai kegiatan sosial lainnya. Sedangkan sosolot adalah sistem barter yang menyebabkan terjalinnya kekerabatan sosial antara orang Seram Laut dengan orang Sorong. ${ }^{12}$

Laporan lainnya tentang migran Buton adalah dari seorang Antropolog Amerika yang datang pada tahun 1950 di Tulehu. Ia melaporkan bahwa orang Buton mempunya posisi istimewa karena mereka adalah masyarakat yang paling banyak datang ke Maluku sejak pertengahan abad dua puluh. Orang Ambon menyebut orang Buton sebagai Binongko, sebuah kata yang mengacu pada orang terbelakang di sebuah wilayah di Sulawesi Tenggara. Orang Binongko jarang mandi dan bau. Pada tahun 1950an, orang Binongko kebanyakan bekerja di kebun. Mereka tidak mempunyai akses ke birokrasi dan pendidikan. Kennedy melaporkan bahwa banyak orang Buton yang mendapatkan sewa tanah secara gratis menggarap kebun karena bekerja beberapa hari di orang-orang Tulehu. Oleh karena itu, orang asli Ambon menganggap remeh orang Binongko karena mereka bukanlah orang asli. Tanah-tanah dimiliki secara kolektif oleh orang Asli. Mengingat orang Buton dan etnis lainnya tidak memilik hak milik tanah, banyak dari mereka yang juga bekerja perikanan dan perdagangan. Kennedy juga melaporkan bahwa hampir tidak ada orang Ambon yang mau

${ }^{12}$ Ellen, Roy. 2002. "Pengetahuan tentang hutan, transformasi hutan : ketidakpastian politik, sejarah ekologi, dan renegosiasi terhadap alam di Seram Tengah" dalam Proses Transformasi Daerah Pedalaman di Indonesia edited by Tania Li. Yayasan Obor Indonesia. 
menikah dengan orang Buton karena klas mereka yang lebih rendah. $^{13}$ Mereka yang menikahi orang Buton adalah orang-orang yang putus asa dalam mendapatkan masyarakat asli Ambon. Khususnya perempuan Ambon, mengingat mereka tidak boleh mengambil inisiatif untuk melamar laki-laki, dan jika tidak ada laki-laki yang melamarnya, maka perempuan tersebut akan menikahi laki-laki Buton.

Dalam level makro, monetisasi di Indonesia Timur juga disebabkan oleh deregulasi yang dilakukan oleh pemerintah setelah pasca meledaknya harga minyak di pasaran dunia pada tahun 1982. Pemerintah mendorong perdagangan antar pulau yang dilakukan oleh pengusahapengusaha besar. Sektor-sektor ekonomi seperti pertanian, manufaktur dan perdagangan mulai berkembang karena pemerintah mencoba untuk meningkatkan pendapatan melalui pajak-pajak domestik non minyak. ${ }^{14}$ Booth juga mengindikasikan bahwa ekonomi Indonesia pasca colonial juga ditandai dengan perkembangan investasi swasta pada para para peladang dan pedagang skala kecil, yang memproduksi tanaman komersial, seperti karet, pala, tembakau, lada, dan the. Meskipun jenis pekerjaan pedagang dan peladang skala kecil hanya memerlukan

13 Raymond Kennedy. 1955. Field notes on Indonesia: Ambon and Ceram, 1949-1950, ed. By Harold Conklin. HRAF. h. 60.

${ }^{14}$ Anne Booth. 1988. Agricultural Development in Indonesia. Sydney: Asian Studies of Australia with Allen \& Unwin. h.197-198. perangkat sederhana dan perekrutan pekerja sangatlah sederhana, Booth mencatat bahwa ratarata penghasilan tanaman komersil secara nasional sangatlah pesat dibanding hasil dari perkebunan skala besar. ${ }^{15}$

Bank hanya buka pada waktu tertntu. Untuk memproses aplikasi pinjaman, bank memerlukan kontrol pengawasan yang sangat kompleks. Banyak surat fotokopi, kartu identitas, kontrak kerja dan tanda tangan dari pengawas. Sebaliknya, pemilik toko dan perantara meminjamkan uang hanya berdasarkan kepercayaan, kekerabatan dan ketetanggaan.

Data ini menunjukkan bahwa masyarakat di tingkatan bawah, seperti pedagang kecil lebih mengandalkan pinjaman dari perantara dibanding dari bank. Dengan kata lain, saya berpendapat bahwa para semakin besar pemilik toko, semakin besar pula kemungkinan relasinya dengan Negara melalui pinjaman, dan sebaliknya.

\section{DAFTAR PUSTAKA}

Adam, Jeroen. 2010. Communal violence, forced migration \& social change on the island of Ambon, Indonesia. Ghent: Ghent university Bartels, Dieter, 1977, "Guarding the invisible mountain: inter village alliances, religious syncretism and ethnic identity among Ambonese Christians and Moslems in the

\footnotetext{
${ }^{15}$ Ibid. 149
} 
Moluccas" PhD Dissertation, Cornell

University, 1977

Benda-Beckmann, Franz von and Keebet von Benda-Beckmann. 2007. Social Security Between Past and Future. Ambonese Networks of Care and Support. LIT Verlag Munster.

Booth, Anne. 1988. Agricultural Development in Indonesia. Sydney: Asian Studies of Australia with Allen \& Unwin.

Ellen, Roy. 2002. "Pengetahuan tentang hutan, transformasi hutan : ketidakpastian politik, sejarah ekologi, dan renegosiasi terhadap alam di Seram Tengah" dalam Proses Transformasi Daerah Pedalaman di Indonesia edited by Tania Li. Yayasan Obor Indonesia.

Hospes, Otto. 1996. People That Count: Changing Savings and Credit Practices in Ambon, Indonesia. Wageningen: publisher not identified. Thesis Wageningen Agricultural University.

Kennedy, Raymond, 1955. Field notes on Indonesia: Ambon and Ceram, 1949-1950, ed. By Harold Conklin. HRAF

Polanyi, Karl. 2014. The great transformation: the political and economic origins of our time. Boston, Mass: Beacon Press.

Scott, James C. 2008. Weapons of the Weak: Everyday Forms of Peasant Resistance. Yale University Press. 